\title{
Democracy, Development and Industrial Policy in Nigeria
}

\section{A Historical Contextualisation}

\author{
Abel B.S. Gaiya
}

Abstract: The article places Nigeria's political and economic challenges in historical and global context. As opposed to viewing democracy or development emerging simply as the 'will of the people' or 'political will', it encourages a historical and structural view of the phenomena. Sustained democratic institutions and intensive economic growth emerge under particular conditions where the continued maintenance of hegemony and gate-keeping extractive states are no longer viable. A diversified capitalist class and economic power among a strong middle class are needed to demand greater democratic accountability. Industrial policy is essential to creating the structural change required for their emergence. Yet the dispersed and ethno-religiously fragmented distribution of power makes industrial policy implementation difficult. Given the salience of such historical and structural forces, postcolonial Nigerians should be seen as formative generations. Students and practitioners of development economics, policy and politics should be more creative in producing politically informed policies for the country.

Keywords: economic history, industrial policy, Nigerian development, Nigerian democracy, Nigerian politics, political settlements

Nigeria is one of the most problematic countries in the world. Even before independence, all regions threatened to secede at some point during constitutional negotiations. The country has tried both parliamentary and presidential systems of governance. It has attempted both federalism and unitary systems of government. It has gone 
through both democratic and military rule, and attempted state capitalism and privatisation, marketisation and liberalisation. Various actors have sought to resolve differences through civil war, insurgency and authoritarian repression. Yet with sixty years of all these experiments, GDP per capita (constant, in 2010 US dollars) in 2019 remains just 11.2 per cent above the 1977 level (World Bank 2021a); poverty rates remain high and the country scores poorly on human development indices, especially in its Northern region (Ita 2020). In addition, a developmental structural transformation of the economy has not occurred (Pwc 2018), and political, bureaucratic and private sector corruption and poor governance prevail. The country also experiences terrorist and pastoral attacks, as well as organised discontentment in all its regions. It is therefore unsurprising that it struggles a lot with establishing and deepening democratic institutions, systems and values.

Nigerians are attempting to construct an inclusive democratic political system, one without institutional biases based on gender, occupation, slavery and religion. This is being done where it has never existed in the geographical territory called Nigeria since the socially stratified Nok civilisation appeared during the Iron Age, until 1960 when Nigeria received formal political independence from a European power. Since falling under the European power's colonial occupation in the late nineteenth century, the past twentyone years since the onset of the Fourth Republic in 1999 is perhaps the longest that Nigerians have gone with universal suffrage, without the disruption of formal authoritarianism. Yet this 'progress' remains precarious, with the country being at risk of being a failed state (Financial Times 2020).

In addition, since passing through the Neolithic revolution, which ushered in agriculture 10,000 years ago, through periods of agricultural elaboration over 5,500 years ago and merchant-based commerce 3,000 years ago (Ehret 2014), Nigeria of the twentieth century is the first to attempt to institutionalise a system of production which produces sustained intensive economic growth. Compared with precolonial economic growth rates that were based on limited proto-industrialisation and land-extensive agricultural production rather than labour- or capital-intensive production (Austin 2008), the postcolonial economic growth rates have probably been 
the highest recorded (de la Escosura 2012: 37; World Bank 2021b) since the first human settlement about 11,000 years ago near Akure in the geographical expanse of Nigeria. But they have been episodic, not sustained, more moderated in per capita terms; and based on raw material production, not structural transformation. Therefore, postcolonial and Fourth Republic Nigerians are a formative generation, even though they often fail to realise it. Their task is not trivial; neither should it be considered normal. It should thus not be reduced to general statements about democracy being the 'will of the people', or development policy only needing 'political will'.

This article serves as a guide to the big picture of democracy and economic development in Nigeria. It seeks to contextualise the challenge in world history and moves to the specifics of Nigeria. It draws from literature on the structural origins of democracy to argue that for democracy to emerge, a decentralised distribution of power within and beyond the elite classes must be present. This involves the rise of a diversified capitalist class and middle classes. However, the emergence of these classes often requires existential threats to the state or economic crises to enable a disruption of growth-reducing political settlements and the implementation of industrial policy. Strong capitalist and middle classes are also necessary to continuously lobby for development policies. The extent to which ruling elites are responsive to these demands or take the initiative themselves is also strongly influenced by the prevailing concentration or dispersion of the distribution of power - that is, the political settlement. In Nigeria, where political settlements are characterised by greater dispersion of power and reliance of ruling elites on oil rents, there is not only low responsiveness of ruling elites to developmental demands of weak capitalist and middle classes, but also greater difficulty in implementing industrial policy. Hence creative and innovative experimentations must be developed to navigate such turbulent political settlements.

The narrative therefore begins with the general and evolves into the particular, from the big picture to policy exploration. Section 2 outlines the structural origins of democracy; Section 3 details the requirements for successful industrial policy in Nigeria; Section 4 proposes avenues for creative experimentation in Nigerian industrial policymaking; and the article concludes with brief warnings for the future. 


\section{Structural Origins of Democracy}

Democracy is not simply the result of 'the will of the people' or 'political will' among elites. Since the Neolithic revolution, the political norm across large agricultural-based societies around the world has been un-democratic (Diamond 1997). Some have called this the 'natural state', characterised by limited access of economic and political resources, power and organisation to a narrow set of elites (North et al. 2009). These elites would often retaliate with violence if the distribution of resources were altered in mismatch with the distribution of power. The Hobbesian Leviathan that is the state may be useful for preventing complete social anarchy under certain circumstances by monopolising the legitimate use of violence. Yet it is maintained by a class of elites that systematically employs the means of violence to grow and preserve its power, and to extract resources from common peoples.

In Nigeria's case, the overarching dependence of the state and ruling elites on oligopolistic oil rents, and the weak capitalist and labouring classes concentrates political power among a small class of elites. This insulates them from democratic accountability and the demands of most of the population. The state therefore becomes as a source of wealth and patronage for elites, extending to extractions from the private sector through corrupt and exploited regulations, off-budget spending, private sector corruption, and demands for bribes and extortions from the populace by civil service, public officials, and law enforcement agents. Just as premodern aristocrats and monarchs contended among one another to gain power and plenty and to establish dynasties, local, state and federal leadership aspirants today use violence, patronage and clientelism as tools for casual electoral, political and bureaucratic rivalries.

North et al. (2009: xii) estimate that 'Perhaps . . . 175 countries and 85 percent [of the world's population] live in natural states' (North et al. 2009: xii). Although democracy is now the normative norm around the world, the world thinks that democracy is empirically the norm only because advanced capitalist-democratic states dominate the global media and intellectual space.

Limiting the despotic power of the state and of elites in a productive manner requires a diversified class of elites - which by itself produces competitive oligarchy (Dahl 1971). It also requires 
a system of decentralised production or economic power - including a wider distribution of landownership during the transition to capitalism (Hundt and Uttam 2017) - which enables a middle class to emerge and fight for mass enfranchisement (Moore 1966). The state must then be dependent upon taxes or military capacity gained from these decentralised economic actors operating in a complex economic system; and political elites must depend on formal funding from productive activity to finance political mobilisation. When the costs of repression are too high, elites have no other choice than to concede to the demands for power-sharing with the powerful populace (Acemoglu and Robinson 2006).

It is therefore not difficult to see that [androcentric and slaveexcluding] democracy arose in Athens thousands of years ago for specific political economy reasons. Athens was a small city-state facing severe economic and political crises and factional conflicts (Gaeta 2004). Its variegated geography facilitated its existence as a small independent city-state, in contrast to Egypt, Persia and China, which could be controlled from a central capital (Stark 2014). It was the intense competition among elites of equal power that led to the creation of a constitutional settlement by Soron in 594 BC. The resurgence of inter-elite conflict then led Cleisthenes, ninetyfour years later, to ally himself to the common people by proposing constitutional reforms that would offer them wider political rights (Tridimas 2011). A major driver of this was the decentralisation of military power away from the aristocracy through the emergence of the hoplite phalanx military formation (Vasillopulos 1995: 52). It is also why small societies with low population densities and elites with equally matched powers and segmentary lineages in Africa (Moscona et al. 2018) tended to have less political centralisation (Herbst 2000) and less despotic political systems before European colonial interference (Mamdani 1996).

It is also no wonder that, during the late Middle Ages, small merchant cities such as Venice, Genoa and Holland made up most of the European republics when the rest of Europe was ruled by emperors, dukes, feudal elites and archbishops (Stark 2014). The Italian city-states such as Venice and Genoa dominated the Mediterranean trade, enabling the dispersion of political power among fairly equally matched interest groups such as bankers, merchants, the aristocracy, clergy, workers' guilds and clergy (Stark 2014). 
These large groups of merchants 'used their new-found muscle to push for constraints on the executive' (Puga and Trefler 2014: 753), enabling Venice to keep democratic tendencies alive when 'the politics of Europe was monarchical and hierarchical, feudal, brutal and unfair' in the Middle Ages (Stockwell, 2011: 105).

Even the pioneering 1215 Magna Carta and the 1689 British Bill of Rights had specific socioeconomic configurations which enabled their emergence in England. Following the fall of the Western Roman Empire in the fifth century AD and the political anarchy that ensued, military power and economic production in Europe became more decentralised. This increased the power of feudal elites vis-a-vis the monarch, thereby pressuring rulers to consult these feudal elites in order to gain armies and funding for their wars and for royal coffers (Blaydes and Chaney 2013). This culminated in the 1215 Magna Carta in England. With state centralisation, rise of absolutist states and monarchs' creation of standing armies, the dependence on feudal military forces was replaced by the need to rely on elites to fund standing armies and war-making. This, as well as the further diversification of the elite class into a commercialised and industrial bourgeoisie characteristic of formative capitalism, underpinned the 1688 Glorious Revolution and 1689 Bill of Rights (Khan 2018). Further gains in expanding the suffrage were made following demands by the industrial labour class and middle class of the nineteenth century (Moore 1966). In other words, while it may be beneficial to read the political philosophies of Plato and Aristotle, and of John Locke and Thomas Jefferson, it is just as important to study the structural conditions within which they theorised about the demos.

Mauritius is able to have democracy, and more so social democracy, because it developed a capitalist class and a labour class that were able to fight for democratic and social democratic concessions (Lange 2003; Sandbrook 2005). Even the extent of democratic scope is aided by structural factors. Slovenia, and many of the Scandinavian countries of continental Europe are able to have not just a liberal democratic minimum, but also some degree of industrial, economic and social democracy due to their economic structures which increase the bargaining powers of workers, compared to liberal market economies like the US and UK (Hall and Soskice 2001; Crowley and Stanojevic 2011). Sustained democracy does 
not therefore emerge simply because of political will or the will of the people when the structural preconditions are absent. These preconditions were absent for Nigeria in 1960, and they remain largely absent today.

Nigeria needs a strong, diversified capitalist class, robust middle class and organised labour which can lobby effectively and fund the electoral campaigns of political elites. These classes are also needed to pay taxes and thereby enforce the state's adherence to rule of law and more efficient provision of public goods and services and coordinate more effectively in protesting against infringements on democratic accountability and workers' rights. For these classes to emerge, structural transformation is essential. Structural transformation entails the movement from traditional and low productivity activity (traditional agriculture) to modern and higher productivity ones (manufacturing and high productivity services).

Nigerian ruling elites are typically satisfied with a low level of development because oil rents facilitate the sustenance of ruling elites but without risking large scale, nationally engulfing anarchy or systemic vulnerability. This intransigence of ruling elites and oligarchs is why it was due to the pressures of war and the need for revenues and credit to carry out defensive and offensive wars that England, the Dutch, and France underwent state consolidation, financial revolutions and industrial policy implementation since the early modern period under 'enlightened despotism' (Reinert 2011) or 'civilised monarchy' (Stapelbroek and Trampus 2010). In fact, the term 'political economy', coined by Antoine de Montchretien in 1615 , 'was born in a context of intense international competition and explicitly institutionalised as a vehicle of emulation' (Reinert 2011: 4-5). Mercantilism, which preceded classical liberal economics, was the economic corollary of European warfare and reason of state. Thus, the idea of economic development was both 'an early mercantilist innovation' (Reinert and Reinert 2011: 13) and an instrument of warfare. Therefore, Alexander Hamilton's infant industry argument for the United States was made in within an international military-commercial-diplomatic nexus (Somos 2011). The pressure of war in attracting greater developmental attention from ruling elites is seen not only in Western Europe, but also in the Ottoman Empire (K1lınçoğlu 2017), Prussia, (Kopsidis and Bromley 2016), the Russian Empire (von Laue 1951: 179-180), China (Gregor and Chang 
1982) and many other states around the world. Egypt became the first Afro-Asian state to attempt comprehensive modernisation from 1804, and Japan became the first non-Western state to industrialise from the 1868 Meiji Restoration, in response to European security threats. The more recent post-World War II East and Southeast Asian developmental states also faced such systemic vulnerabilities owing to communist threats, which drove their industrial policy experience and developmental states (Doner et al. 2005).

This effect is visible in Africa as well. Sultan Muhammad Bello's post-jihad policies for economic development in the early nineteenth century Sokoto Caliphate were closely linked with caliphal defence (Chafe 1994: 102). The modernisation attempts of Abyssinia from the mid-1850s and at the turn of the century were in reaction to Egyptian and Italian security threats, respectively. The 1990s Eritrean War galvanised the Ethiopian state for developmental governance (Clapham 2018: 1155), and the 1994 Rwandan Genocide made salient the need for a new political settlement and legitimacy sought through delivery of development outcomes (Mann and Berry 2016).

When Nigeria's ethnic divisions culminated in the civil war (1967-1970), the war unfortunately ended at a time of a spike in oil prices, which gave the state easy sources of revenue, in contrast to post-genocide Rwanda. Ruling elites resorted to superficial developmentalism in the form of inflationary civil service wage increases (Udoji awards), massive (and massively and unproductively corrupt) infrastructural spending (Marwah 2020) and inefficient state-owned enterprise expansion based on import-substitution industrialisation. Meanwhile agriculture went into decline and emerging manufacturing industries were too import-dependent, funded by oil export earnings and thus not complimented by the development of an ambitious export-oriented industrialisation strategy as was the case with South Korea and Taiwan (Rodrik, Grossman and Norman 1995). Indonesia, a country similar to Nigeria in some respects, was able to escape this resource curse because, among other factors, it faced threats of communist insurrection and had a stronger capitalist base than Nigeria had (Rosser 2007). In general, the relative lack of the threat of war in postcolonial Africa and nineteenth century Southeastern Europe limited pressures for state-building and structural transformation (Herbst 2000; Malešvić 2012). 
Economic, fiscal and balance of payments crises associated with a crash in international commodity prices or trade imbalances also often incentivise greater effort by ruling elites in developing countries to substitute imports for domestic consumption goods and to increase exports to gain foreign exchange. The efforts made by some Spanish and Portuguese thinkers and elites to reverse Iberian decline in the eighteenth century are examples, although unsuccessful due to the power of feudal and bullionist elites and easy access to colonial mineral revenues (Perrota 1993; Almodovar and Cardoso 1998). The Merina Empire embarked upon a modernisation programme in reaction to the loss of royal revenues and exports from the slave trade linked to the 1820 Anglo-Merina anti-slave trade treaty. Many Latin American countries and South Africa also pursued this course during the Great Depression. It was also economic crisis, precipitated by the Cultural Revolution (1966-1976) that created popular pressure to raise living standards and forced China to transition from socialism to a developmentally oriented state capitalism (Huan 1986: 2).

Without such military and economic pressures, and/or without a strong industrial capitalist base lobbying for industrial policy, ruling elites typically depend on promoting commodity production and other easier economic activities (Cooper 2005). This is fine with them as long as it facilitates basic social stability (notwithstanding limited, disparate and occasional protests, crime, violence, insurrections and low-intensity civil wars), ruling class reproduction and basic electoral demands such as majority employment rate and (episodic and non-inclusive) economic growth. High unemployment rates are tolerated, and employment is mostly composed of informal or precarious employment, underemployment, low incomes and high poverty levels.

Collective action problems make it difficult to spur and coordinate the populace to protest (Olson 1965), made worse by a weak industrial class (Rudra 2002). Protest therefore remains low in frequency and scale unless spurred by largescale and widespread shock. In other words, as long as social instability is limited to repressively 'contained' pockets of violence such as IPOB (Independent Peoples of Biafra) in the south-east, MEND (Movement for the Emancipation of the Niger Delta) in the south-south, Boko Haram in the north-east, and occasional sporadic protests, then 
ruling class reproduction may proceed without significant interruption. These movements have arisen from various forms and levels of political and economic exclusion, both ethnically motivated and class-motivated. However, the economic component of their struggle (such as the federal marginalisation of the south-east, immiseration of the Niger Deltans due to oil extraction, and poverty and deindustrialisation in the north) is left unaddressed since the ruling elites are largely insulated from the consequences of economic marginalisation of these groups.

Even when such violence and protests erupt, the first recourse is always the use of force to repress oppositional movements and maintain the status quo distribution of resources, and perhaps some superficial gestures of concession and side payments to leading elites of such movements (as given to Niger Delta elites). The protests can, however, produce a marginal alteration in the distribution of resources and restrictions in certain means of oppressing and extracting from the masses. Hence the Niger Delta militancy, threatening the oil-based financial core of the ruling elites, pressured the transfer of some finances to the region under the (highly imperfect) 2009 Presidential Amnesty Programme and Niger Delta Development Commission.

With and without crises, for strong capitalist and middle classes to emerge there is a need for structural transformation. To promote industrial and agricultural transformation, industrial policy needs to be implemented. This has been the case for all countries, from fifteenth century Tudor England to twentieth century East Asia and Latin America (Chang 2002; Reinert 2007).

Formal colonialism wasted about fifty years of potential independent attempts at proper sovereign modernisation for Nigeria and many other African countries, especially those with higher levels of precolonial political centralisation (Heldring and Robinson 2012). This left the post-independence generations to deal with both the lag and the domestic barriers created by colonial powers and the persistent precolonial challenges (Herbst 2000). These include poor and distorted state consolidation (weak bureaucracies and ethnic fragmentation), a weak capitalist and labour class, and non-diversified economies. Nonetheless, recent research using the political settlements framework reveals the preconditions for successful industrial policy implementation given the distribution of power across society. 


\section{Requirements for Successful Industrial Policy in Nigeria}

Political settlements theory and evidence suggests that for industrial policy to emerge and be successful, at least three major factors must be present. These include mutual interests between ruling elites and capitalists to initiate industrial policy in a particular industry; pockets of bureaucratic efficiency to implement the industrial policy without the interference of disruptive politics and corruption; and the facilitation of learning for productivity growth of capitalists who receive industrial policy support (Whitfield et al. 2015). A major problem with Nigeria is with its political settlement - that is, the distribution of power that determines the distribution of benefits across society (Khan 2010). Nigeria is characterised by ethnoreligious fragmentation (Usman 2020), inter-regional economic inequalities (Green 2011) and lack of a class-based unifying ideology (Dickovick 2008).

Nigeria's instabilities transverse four general axes: north-south, Christian-Muslim, Igbo-Hausa-Yoruba, and majority-minority ethnicities (Owen and Usman 2015: 456). Fractionalisation has played out, since colonial times, in the form of political mobilisation mainly based on patronage, ethnic, religious and regional identities, rather than on class and political ideology. The British amalgamated multiple political and social communities into a single political unit, and yet employed divide and rule strategies to govern the colony (Ray 2016). Given the agrarian economic structure and lacking strong class identity or ideologies, political mobilisation was undertaken a regional and ethnic basis. The Willinks Commission - the most comprehensive attempt at reconciling multi-ethnicity in the colony - ended up worsening ethnic cleavages (Oduntan 2017). Thus, during precolonial constitutional negotiations, each region threatened separate national independence at least once, only being placated with assurances of regional autonomy under the institutional arrangement of regional federalism (Ayoade 1973). This, as well as the lack of economic transformation to strengthen class identity over ethnic, religious and patrimonial identities and networks, therefore makes politics fragmented. Attempts to consolidate power by centralising power, as Aguiyi Ironsi attempted in 1966, have failed. The implication is that ruling coalitions since independence have faced both intense competition from excluded 
elites, and internal contestation among elites and their followers within the ruling coalition as well.

Democracy in Nigeria is therefore characterised by 'competitive clientelism' and military rule is characterised by 'vulnerable authoritarianism' (Roy 2017). Both democracy and authoritarian rule in Nigeria are thus unstable, demonstrated by the very short tenures of military rulers, and the vulnerability and political instabilities of civilian rule. This gives ruling elites a short-term horizon, focusing on maintaining power and partaking in unproductive corruption, rather than having a developmental orientation. This is unlike the Chinese Communist Party or Botswana People's Party (Beaulier and Subrick 2006), which face much less competition from excluded elites and less internal contestation from within their ranks. This is partly due to less ethnic heterogeneity and fragmentation, as well as postcolonial/post socialist continuity of precolonial/socialist-era political legitimacy. Nigerian ruling elites with a short-term horizon are less likely to initiate, sustain and make successful industrial policy for long-term growth. This is worsened by a dependence of the state on oil revenues, since this concentrates the state's revenue dependence on one sector, and thus widens elites' distance from already-weak capitalists and the populace who desire productive mutual interests between themselves and the ruling elites.

The disadvantage does not end with ruling elites having a shortterm horizon. Competitive clientelism also makes the enforcement of industrial policy very difficult. In other words, even if a leader had the 'political will' to develop a particular industry, the contestation of power and distribution of rents within the ruling class and the pressures to maintain power and pacify several interests means that they are less able to adequately secure the autonomy of, and control over industrial policy implementing agencies. They would find it difficult to prevent the industrial policy supports from being used instead for personal enrichment without delivering greater economic performance. For instance, the Customs Service and Ministry of Finance can resist implementation of duty waivers; it is difficult to enforce tariffs or import bans when customs officials at the borders allow smuggling for personal gains; and monitoring of infrastructure projects and contractors across multiple and dispersed locations becomes difficult. 
A few examples will be illustrative. In Taraba State, the foreign-owned company Dominion Farms Ltd attempted to establish a 30,000-hectare rice farm in 2012 (Burgess 2015). It tussled with the finance ministry and customs to access import duty waivers, while clearing agents ignored the president's directive at the ports; it was caught in the crossfire of gubernatorial tussles for power, and the Upper Benue River Authority refused to comply with a presidential directive to vacate the land that Dominion Farms was to use (Burgess 2015). It was also the case with the Jonathan-era cotton-textile value-chain policy, where powerful importers' interests in Kano State limited policy success. A further contribution to failure was the contestation between Customs and the Ministry of Finance over import duties on one hand, and between the Ministry of Agriculture and Ministry of Industry over financing focus on the other hand (Aremu et al. 2017).

It can also be seen in the case of oil refineries where efficient management is systematically disrupted by elites and their followers within and outside the ruling coalition (Usman 2020). President Obasanjo was always distrustful and paranoid over the influence of the vice president, Atiku Abubakar, in the Bureau of Public Enterprises over privatisation of state-owned enterprises (El-Rufai 2013). Even with fiscal policy this problem is apparent, as with the opposition from state governors to the Excess Crude Account proposed by the Minister of Finance under President Goodluck Jonathan (Channels Television 2012).

These problems are visible in many other industries, industrial policy tools and implementing agencies - customs officers undermining tariff policy and fostering smuggling; bureaucrats siphoning away funds and undermining small and medium enterprise development policy; gross abuses of import duty waivers; massive holes in infrastructure investments and projects; and so on. State-owned enterprises established between independence and the 1980s largely failed, unlike in China or South Korea, because of the inability of ruling elites to keep a long-term horizon and to shield the enterprises from growth-reducing political interference. In contrast to the New Order regime of Indonesia's Suharto in the 1960s where corruption was 'organised', 'centralised' or 'franchised', Nigeria was unable to centrally coordinate corruption and direct it into growth-enhancing activities (Enweremadu 2013). The most 
operationally efficient agencies tend to be those involved directly in managing the finance of the state and hence the reproduction of ruling elites (Hickey 2019) - the Ministry of Finance, Central Bank of Nigeria, and Federal Inland Revenue Service. Even they are not without their limitations, often facing difficulties forcing ministries departments and agencies to remit revenues, difficulties enforcing financial regulations and difficulties collecting tax revenues from Nigeria's elites.

While the Fourth Republic Nigerian economy has diversified into services, but still remains largely agrarian and non-industrial, there have been some industrial policy successes. It is easy to see the constellation of factors involved. An important example is that of the domestic cement manufacturing industry which has grown and has even become a foreign-investing industry in Africa (Itaman and Wolf 2019). The early years of the Fourth Republic were a time of economic and fiscal crisis, following the turbulence of an oil price crash, structural adjustment programming, and an extremely low foreign image of the country since the 1990s. The ruling coalition was desperate for economic growth, employment generation and growing state revenues. Revamping the inefficient state-owned enterprises was no longer an option, even though President Obasanjo initially wanted to do so. Crisis forced him to seek mutual interests with various capitalist and mercantile actors. Aliko Dangote, who had been a major cement importer and marketer, took advantage of the opportunity to lobby for industrial policy support to enter into domestic cement manufacturing (mutual interests established). The supports included purchase of state-owned cement producing companies, fiscal incentives, credit guarantee, and a cement import ban and licensing scheme. Similarly, the telecommunications industry underwent drastic changes and rapid growth because the same crisis broke the monopoly power and influence of Nigerian Telecommunications Limited (NITEL) elites, and enabled the state to bring in foreign players with technological and organisational capabilities who could compete in a large economy (Usman 2020). On the other hand, the oil refining industry did not undergo transformation because of the power of the labour unions that opposed the privatisation of the state-owned refineries (Usman 2020). It was also constrained by the absence of capitalists with enough technological and organisational capabilities to build a large refinery despite the 
constraints of the anti-privatisation, fuel subsidy, and oil importing and marketing lobbies.

In summary, war and generalised economic crises provide largescale pressures for reforms, policies and growth-enhancing political settlements (for the survivors). The task during normal periods is to find small, occasional windows for feasible, politically-informed and effective sectoral reforms and policy implementation with the hope of a long-term expansion in the tax base, capitalist and middle classes. These social forces then push the level of lobbying for productive policies into a higher equilibrium level over time. This is more difficult in countries where the political settlement is highly fragmented and power is dispersed. In such countries, more creative ways to establish mutual interests, facilitate pockets of bureaucratic effectiveness, and enforce learning for productivity must be sought.

\section{Creative Experimentation for Nigeria's Progress}

Nigeria's ethno-religious fragmentation and political fractionalisation and fluidity make it difficult to consolidate power to implement development policy effectively, especially in the absence of major security and fiscal crises and strong capitalist and middle classes. This also limits the emergence and strength of democratic forces.

The absence of war and radical communist threats means that radical alteration of the political settlement and distribution of rents is infeasible, expect perhaps during generalised economic crises. Scholars and policymakers must therefore think creatively about navigating and working through the political settlement and find new ways of generating mutual interests between private economic actors and ruling elites; of facilitating pockets of bureaucratic efficiency for industrial policy implementation; and of ensuring that recipients of industrial policy support deliver in terms of productivity.

In addition to broad-based socioeconomic development, the aim is to create a diversified business class and a robust middle class that the state can rely on for tax revenues (and eventually rival oil revenues) and political elites can rely on for party and campaign financing. This gives the capitalist and labour class greater structural and instrumental power to lobby more effectively for 
the state's and elites' adherence to rule of law, democratic norms, more efficient public services, and better public goods provision such as education and infrastructure. Hence, Aliko Dangote is in a better position to lobby for improvements in Nigeria's port capacity given that its trading activities have reached the capacity of the Apapa port and the Dangote Group has grown in structural power. Long-term reduction of corruption also depends on these structural forces, rather than overly simplistic prosecution and 'social norms' approaches (Khan 2010).

Creative solutions must be able to exploit variations in power and organisational capabilities across different scales of social organisation (state, federal and international) and different sectors (public and private). I propose four avenues for exploration and experimentation in Nigeria: leveraging the adaptive capabilities of large firms, multilaterally-assisted ex post industrial policy, including the Economic and Financial Crimes Commission in industrial policy enforcement, and leveraging variation in subnational industrial policy enforcement capabilities.

The state's difficulty in implementing industrial policy necessitates more self-organising capabilities among capitalists. Building diversified business group is one important way for corporations to diversify risk, increase their political influence, and circumvent politico-bureaucratic bottlenecks in industrial policy implementation. This was an important factor in the success of the Dangote Group in the cement industry and its ongoing massive investments in the oil refining industry (Gaiya, 2020). Even the mighty Aliko Dangote and his cement interests had to wrestle with the change in cement policy which came with a change in political power from the Obasanjo to the Yar'adua presidency, as well as the incapacity of the government to reliably provide infrastructure despite his political influence. Moreover, evidence shows that although power, corruption and a swathe of other challenges are rated by businesses to be the top challenges to production in Nigeria, large firms are better able to absorb the higher costs associated with these bottlenecks.

In addition to the Dangote Group, another example is found in the case of Edo State. Some have observed that in Nigeria's Edo State's road construction project from 2009 to 2013, 83 per cent of all road construction was accounted for by five large contractors 
(Bain et al. 2015: 9). This was because they 'had both financial depth and the links to local banks that were needed to absorb the impact of the state's uncertain cash flows', thereby avoiding interruptions in implementation while allowing the 'inevitable arrears in state government payments to accumulate' (Bain et al. 2015: 9). This is, however, not a long-term solution since businesses still need long-term infrastructure provision and more effective industrial policy provisions to enable adequate investment. Therefore, the long-term strengthening of the state is critical.

Given the difficulties in enforcing capitalists' productive use of ex ante industrial policy support under Nigeria's dispersed political settlement, Khan (2013) has proposed the use of ex post industrial policy support. The typical ex ante support involves giving companies subsidies, tariffs, import bans, and so on before firms make substantive investments, thereby enabling them to enjoy the supports and cash without delivering in performance and productivity growth. Ex post support would be to promise the support/compensation/prize only after the firm made the required investments and achieved the target performance criteria, thereby requiring less demanding public monitoring requirements. Some powerful domestic players could be circumvented, and the support made more credible, if the prize is disbursed to a multilateral agency endowed with a facility to monitor performance and dispense the prizes to the capitalists who make the required investments. The principle behind this is similar to the World Bank's backing giving credibility to the Edo State government in the previous example (Bain et al. 2015); and the World Bank's aid to the Bureau of Public Enterprises enabling it to circumvent legislative and Ministry of Finance politics during the early years of the Fourth Republic (ElRufai 2013). A weakness of this approach is that it would undoubtedly be the large firms and diversified business groups with the financial, organisational and political capabilities to invest without much ex ante state support, which would benefit the most from such a facility. An indication of this possibility may be found in recent events. Dangote Industries Ltd. received a contract with the government to build the Apapa road, but because the government's payment of contractors is uncertain and inconsistent, Dangote proposed instead to be paid through tax credits over a period of three years rather than in cash (Channels Television 2017), which was 
only possible because it had the liquidity to run the project without receiving start-up cash from the state.

With respect to supporting industrial policy implementing agencies, there is potential for experimenting with the systematic involvement of the country's premier anti-corruption agency (the Economic and Financial Crimes Commission, EFCC). I have observed how the EFCC has become involved in some aspects of industrial policy enforcement, particularly recovery of development loans, abandoned infrastructure projects, and local content policy enforcement. The agency received high-level political support from its inception during the Obasanjo-era economic predicaments in order to signal to the international financial community that the country would seriously tackle corruption and be worthy for substantial debt relief. The EFCC also receives political support by the ruling elites due to its electoral instrumentality in signalling seriousness with anti-corruption and in attacking political enemies. This high-level support, investigative capabilities amassed over the years, and credibility of threat of prosecution and conviction may make it beneficial to formally graft into industrial policy enforcement mechanisms. However, there is the risk of over-burdening the agency, and the possibility that the effect of its involvement with industrial policy enforcement is marginal even if positive. Yet it is difficult to say how successful this could be without further investigation.

Furthermore, an area that has escaped the development literature is the importance of local developmental states in driving local development and thus contributing to national development (Bateman 2017). The Nigerian development literature has focused on federal initiatives and institutions, but there is some variation in bureaucratic capacity and political settlements across states. The Nigerian federal government relies predominantly on oil revenues, and the vast majority of states rely on federal transfers. On the other hand, Lagos State enjoys the largest share of internally generated revenues in Nigeria (30 per cent) (Taxaide 2020), hosts the largest share of MSMEs and industries in Nigeria and accounts for over 60 per cent of the nation's industrial and commercial activities (Nwagwu and Oni 2015). Its politics is also much less ethno-religiously fragmented than federal politics. There is some preliminary indication that its industrial policy and tax institutions 
have therefore been more effective and more responsive to commercial and capitalist actors than their federal counterparts (Page and Okeke 2019: 12). In fact, its governor has recently decried the lack of availability of power to use some industrial policy tools to attract foreign investment, and thus has advocated greater policy autonomy from the federal government (Munshi 2021). There is scope for further research into this and the prospects for broadening, grafting or outsourcing Lagos State industrial policy agencies implementation and monitoring capabilities into federal-level industrial policy initiatives. However, since the major industrial policy powers are vested in the federal government, it would be difficult to develop mechanisms to achieve this. Yet pressures for fiscal federalism could provide an opening for introducing such mechanisms into the debate.

Regarding mutual interests, in the long run, as the Nigerian industrial class grows and diversifies; bottom-up growth-enhancing lobbying would also grow (although another battle would be to prevent the economy becoming stuck with domination by monopolistic and oligopolistic actors). In the meantime, creative ways to enlist capital to growth-enhancing uses would be a useful addition to the coterie of ways of establishing mutual interests. Nigeria is awash with much corruption capital; much of it is not put into productive domestic investment and a lot flows out of the country. It could be a fruitful experiment with the EFCC to try out a 'corruption-investment transition' programme. The EFCC could be used as a selection mechanism to identify upper-mid-level corrupt persons who are beyond the reach of both standard litigation and plea bargain. The EFCC could use the threat of anti-corruption investigation and prosecution as leverage to induce threatened corrupt persons and firms into investing in industrial production. This 'corruptioninvestment amnesty' somewhat appeared under the authoritarian regimes of Park Chung-Hee's South Korea (Haggard et al. 1990: 15-16) and Suharto's Indonesia (Enweremadu 2013). It could be modified for a democratic context and the EFCC could be involved in performance monitoring over these amnesty-enlisted businesses. A major weakness that is instantly perceivable is the possibility of such a programme to be co-opted as a means of escaping anticorruption prosecution altogether. To partly mitigate this risk, it could be targeted at corruption-accused actors who already have 
demonstrable entrepreneurial and organisational capabilities, such as through involvement in importation and distribution trades or in primary production.

Although strengthening class identity, rise of strong capitalist classes and middle classes are expected to underpin long-term democratic transformation, the existing ethno-religiously fragmented and patrimonial political mobilisation makes it difficult to implement the policies to create these classes. Some have thus argued that separation is necessary for reducing ethnic fractionalisation to a level that is more manageable for a relatively stable political settlement. However, the dependence of ruling elites on oil rents and subjugation of oil-producing regions, and of northern elites on rents derived from the south, incentivises radical repression against secessionist forces by those with the most power. Policymakers may therefore be stuck for a long time with the difficulties of creatively navigating the political settlement in the presence of high levels of ethnic fractionalisation.

\section{Conclusion}

While there is cause for optimism, there is much more for pessimism as things stand. As much as there are avenues for creative and progressive action, there are many more ways that things can remain bad or worsen. Intensive and sustained economic growth eluded humanity for millennia. Russia has unsuccessfully been trying to industrialise for 300 years (Graham 2013). When Sun Yat-sen made plans towards his vision for China to be 'another New World in the economic sense' (Yat-sen 1922: 9), only over six decades later did this begin to be realised. Economic and social development is not a linear process, and believing so is mere Rostowian ahistorical naivety. In essence, the light at the end of the tunnel for Nigeria may be distant, and the path could be filled with conflict, violence, crises, intermittence of progressive reforms and retractions, and multiple interregna of stagnation. The country may not even be one sovereign body at some point in the next few decades.

Although these transitional generations may suffer, their sacrifice may well give impetus for greater effective developmentalism among ruling elites. Separation could even bring greater 
socio-political stability to each of the new national units. Moreover, Nigeria does not need to be the Giant of Africa to help drive West African progress. The important thing is that some generation in the future can confidently rank Nigerians as having a substantive level of social development and can point to past generations, including this one, as having taken creative and critical actions to help realise that status. This is more poignant given the grand challenges of climate change, automation, African religious and age demographic changes, and hegemonic competition which are set to become more problematic in coming decades.

Abel B. S. Gaiya holds an MSc in development economics from SOAS, University of London. He is interested in the political economy of industrial policy, global economic history, history of African economic thought, international political economy and comparative political economy.E-mail: abelgaiya@gmail.com

\section{References}

Acemoglu, D. and J. A. Robinson. 2006. Economic Origins of Dictatorship and Democracy. Cambridge: Cambridge University Press.

Almodovar, A. and J. L. Cardoso. 1998. A History of Portuguese Thought. London: Routledge.

Aremu, F. A., P. V. Kwaghe, D. E. Agbiboa and S. A. Jijji. 2016. 'Political Settlement Analysis of Employment Creation in Agriculture and Agroindustries in Nigeria', PASGR Working Paper 015. Nairobi: Partnership for African Social \& Governance Research (PASGR).

Austin, G. 2008. 'Resources, Techniques and Strategies South of the Sahara:

Revising the Factor Endowments Perspective on African Economic Development, 1500-2000', Economic History Review 61 (3): 587-624.

Ayoade, J. A. A. 1973. 'Secession Threat as a Redressive Mechanism in Nigerian Federalism', Publius 3 (1): 57-74.

Bain, K., D. Porter and M. Watts. 2015. 'Institutional Change, Political Economy, and State Capabilities: Learning from Edo State, Nigeria', Working Paper 97600. Washington, DC: The World Bank.

Bateman, M. 2017. 'Bringing the Local State Back into Development: The 'Local Developmental State' and the Promotion of Sustainable Economic Development and Growth from the Bottom-Up'. Paper presented at the 29th Annual Conference of the European Association for Evolutionary Political Economy (EAEPE), Budapest, 19-21 October. 
Beaulier, S. A. and R. J. Subrick. 2006. 'The Political Foundations of Development: The Case of Botswana', Constitutional Political Economy 17: 103-115. doi.org/10.1007/s10602-006-0002-x

Blaydes, L. and E. Chaney. 2013. 'The Feudal Revolution and Europe's Rise: Political Divergence of the Christian West and the Muslim World before 1500 CE', American Political Science Review 107 (1): 16-34. doi. org/10.1017/S0003055412000561

Burgess, C. 2015. '(Not) Doing business in Nigeria', Farmlandgrab.org, www. farmlandgrab.org/post/view/24612-not-doing-business-in-nigeria.

Chafe, K. S. 1994. 'Challenges to the Hegemony of the Sokoto Caliphate: A Preliminary Examination', Paideuma 40: 99-109.

Chang, H-J. 2002. Kicking Away the Ladder: Development Strategy in Historical Perspective. London: Anthem Press.

Channels Television. 2012. 'FG blame governors for depletion of excess crude account', Channels TV, 13 April. www.channelstv.com/2012/04/13/fg-blamegovernors-for-depletion-of-excess-crude-account/.

Channels Television. 2017. 'Devakumar Edwin Explains Proposed FG-Dangote Apapa Roads Partnership. www.youtube.com/watch?v=ALvvqmya3ak.

Clapham, C. 2018. 'The Ethiopian Developmental State', Third World Quarterly 39 (6): 1151-1165. doi.org/10.1080/01436597.2017.1328982

Cooper, F. 2005. Africa since 1940: The Past and the Present. Cambridge: Cambridge University Press.

Crowley, S. and M. Stanojevic 2011. 'Varieties of Capitalism, Power Resources, and Historical Legacies: Explaining the Slovenian Exception', Politics \& Society 39 (2): 268-295. doi.org/10.1177/0032329211405440

Dahl, R. A. 1971. Polyarchy: Participation and Opposition. Connecticut: Yale University Press.

De La Escosura, L. P. (2012). 'Output Per Head in Pre-Independence Africa: Quantitative Conjectures’, Working Papers in Economic History WP 12-11. Madrid: Universidad Carlos III de Madrid.

Diamond, J. 1997. Guns, Germs, and Steel: The Fates of Human Societies. London: W.W. Norton \& Company.

Dickovick, T. J. 2008. 'Legacies of Leftism: Ideology, Ethnicity and Democracy in Benin, Ghana and Mali', Third World Quarterly 29 (6): 1119-1137. doi. org/10.1080/01436590802201089

Doner, R. F., B. K. Ritchie and D. Slater. 2005. 'Systemic Vulnerability and the Origins of Developmental States: Northeast and Southeast Asia in Comparative Perspective', International Organization 59: 327-361. doi. org/10.1017/S0020818305050113

Ehret, C. 2014. 'Africa in World History before ca. 1440', in E. Akyeampong, R. H. Bates, N. Nunn and J. A. Robinson (eds), Africa's Development in Historical Perspective. New York: Cambridge University Press, 33-55.

El-Rufai, N. A. 2013. The Accidental Public Servant. Ibadan, Nigeria: Safari Books. 
Enweremadu, D. U. 2013. 'The Impact of Corruption on Economic Development: Comparing the Experience of Nigeria and Indonesia (19671998)', in B. Berendsen, T. Dietz, H. S. Nordholt and R. van der Veen (eds), Asian Tigers, African Lions: Comparing the Development Performance of Southeast Asia and Africa. Leiden: Koninklijke Brill NV, 197-226.

Financial Times. 2020. 'Nigeria is at risk of becoming a failed state', Financial Times, 22 December, www.ft.com/content/9abc218d-3881-4bfd-8951e76336cde94f.

Gaeta, L. 2004. 'Athenian Democracy and the Political Foundation of Space', Planning Theory \& Practice 5 (4): 471-483. doi. org/10.1080/1464935042000293206

Gaiya, A. B. S. 2020. 'Industrial Policy and Firms' Adaptations to Imperfect Pockets of Efficiency: The Case of Dangote Group', African Journal of Social Sciences and Humanities Research 3 (6): 186-203.

Graham, L. 2013. Lonely Ideas: Can Russia Compete? Cambridge, MA: The MIT Press.

Green, E. 2011. 'The Political Economy of Nation Formation in Modern Tanzania: Explaining Stability in the Face of Diversity', Commonwealth \& Comparative Politics 49 (2): 223-244. doi.org/10.1080/14662043.2011.564474

Gregor, J. A. and M. S. Chang. 1982. 'Marxism, Sun Yat-sen and the Concept of 'Imperialism', Pacific Affairs 55 (1): 54-79. doi.org/10.2307/2756903

Haggard, S., B-K. Kim, and C. Moon. 1990. 'The Transition to Export-Led Growth in South Korea, 1954-66', Working Paper WPS 546. Washington, DC: The World Bank.

Hall, P. A. and D. Soskice. 2001. Varieties of Capitalism: The Institutional Foundations of Comparative Advantage (eds). Oxford: Oxford University Press.

Heldring, L. and J. A. Robinson. 2012. 'Colonialism and Economic Development in Africa', NBER Working Paper No. w18566. Washington, DC: NBER.

Herbst, J. 2000. States and Power in Africa: Comparative Lessons in Authority and Control. New Jersey: Princeton University Press.

Hickey, S. 2019. 'The Politics of State Capacity and Development in Africa: Reframing and Researching 'Pockets of Effectiveness', ESID Working Paper No. 117. Manchester: Effective States and Inclusive Development Research Centre, The University of Manchester.

Huan, G. 1986. 'China's Open Door Policy, 1978-1984', Journal of International Affairs 39 (2): 1-18.

Hundt, D. and J. Uttam. 2017. Varieties of Capitalism in Asia: Beyond the Developmental State. London: Palgrave Macmillan.

Ita, E. B. (2020). 'Human Development in Nigeria', International Journal of African and Asian Studies 61 (1): 40-49.

Itaman, R. and C. Wolf. 2019. 'Industrial Policy and Monopoly Capitalism in Nigeria: Lessons from the Dangote Business Conglomerate', CAE Working Paper 2019:2. Roskilde: Center of African Economies. 
Khan, M. H. 2010. Political Settlements and the Governance of GrowthEnhancing Institutions (Unpublished). https://eprints.soas.ac.uk/9968/.

Khan, M. H. 2013. 'Technology Policies and Learning with Imperfect Governance', in J. Stiglitz and J. Y. Lin (eds), The Industrial Policy Revolution I. The Role of Government Beyond Ideology. London: Palgrave, 79-115.

Khan, M. H. 2018. 'Power, pacts and political settlements: A reply to Tim Kelsall', African Affairs 117 (469): 670-694.

Kilınçoğlu, D. T. 2017. 'Studying Economics as War Effort: The First Economic Treatise in The Ottoman Empire and Its Militaristic Motivations', in Y. Ikeda and A. Rosselli (eds), War in the History of Economic Thought: Economists and the Question of War. London: Routledge, 78-99.

Kopsidis, M. and D. W. Bromley. 2016. 'The French Revolution and German Industrialization: Dubious Models and Doubtful Causality', Journal of Institutional Economics 12 (1): 161-190. doi.org/10.1017/ S1744137415000223.

Lange, M. 2003. 'Embedding the Colonial State: A Comparative-Historical Analysis of State Building and Broad-Based Development in Mauritius', Social Science History 27 (3): 397-423.

Malešvić, S. 2012. 'Wars that Make States and Wars that Make Nations: Organised Violence, Nationalism and State Formation in the Balkans', European Journal of Sociology / Archives Européennes De Sociologie / Europäisches Archiv Für Soziologie 53 (1): 31-63. doi.org/10.1017/ S0003975612000021.

Mamdani, M. 1996. Citizens and Subject: Contemporary Africa and the Legacy of Late Colonialism. Princeton, NJ: Princeton University Press.

Mann, L. and M. Berry. 2016. 'Understanding the Political Motivations That Shape Rwanda's Emergent Developmental State', New Political Economy 21 (1): 119-144. doi.org/10.1080/13563467.2015.1041484.

Marwah, H. 2020. 'Untangling Government, Market, and Investment Failure during the Nigerian Oil Boom: The Cement Armada Scandal 1974-1980', Business History 62 (4): 566-587. doi.org/10.1080/00076791.2018.1458839.

Moore, B. 1966. Social Origins of Dictatorship and Democracy: Lord and Peasant in the Making of the Modern World. Boston: Beacon Press.

Moscona, J., N. Nunn, and J. A. Robinson. 2018. 'Social Structure and Conflict: Evidence from Sub-Saharan Africa', HiCN Working Paper 264. Brighton: Institute of Development Studies, University of Sussex.

Munshi, N. 2021. 'How Lagos loses out in battle for investors', Financial Times, 1 February www.ft.com/content/eca6f672-4ee6-4dd0-94c4-9213294b61fb.

North, D. C., J. J. Wallis and B. R. Weingast. 2009. Violence and Social Orders: A Conceptual Framework for Interpreting Recorded Human History. Cambridge: Cambridge University Press.

Nwagwu, I. and T. Oni. 2015. 'Lagos and Its Potentials for Economic Growth', Heinrich Boll Stiftung, 1 July. https://ng.boell.org/en/2015/07/02/lagos-andits-potentials-economic-growth. 
Oduntan, O. B. 2017. 'Decolonization and the Minority Question in Nigeria: The Willink Commission Revisited', in U. Usuanlele and B. Ibhawoh (eds), Minority Rights and the National Question in Nigeria. Cham: Palgrave Macmillan, 17-39.

Olson, M. 1965. The Logic of Collective Action: Public Goods and the Theory of Groups. Cambridge: Harvard University Press.

Owen, O. and Z. Usman. 2015. 'Briefing: Why Goodluck Jonathan Lost the Nigerian Presidential Election of 2015', African Affairs 114 (456): 455-471. doi: 10.1093/afraf/adv037.

Page, M. and C. Okeke. 2019. 'Stolen Dreams: How Corruption Negates Government Assistance to Nigeria's Small Businesses', Working Paper. Washington, DC: Carnegie Endowment for International Peace.

Perrota, C. 1993. 'Early Spanish Mercantilism: The First Analysis of Underdevelopment', in L. Magnusson (ed), Mercantilist Economics. New York: Springer Science+Business Media, LLC, 17-58.

Puga, D. and D. Trefler. 2014. 'International Trade and Institutional Change: Medieval Venice's Response to Globalization', The Quarterly Journal of Economics 129 (2): 753-821.

Pwc. 2018. Structural Transformation and Jobless Growth in Nigeria. Lagos: Pwc. Ray, S. 2016. 'Sooner or Later: The Timing of Ethnic Conflict Onsets after Independence', Journal of Peace Research 53 (6): 800-814.

Reinert, E. S. 2007. How Rich Countries got Rich . . . and Why Poor Countries Stay Poor. London: Constable \& Robinson Ltd.

Reinert, E. S. and S. A. Reinert. 2011. 'Mercantilism and Economic Development: Schumpeterian Dynamics, Institution Building, and International Benchmarking', OIKOS 10 (1): 8-37.

Reinert, S. A. 2011. Translating Empire: Emulation and the Origins of Political Economy. Cambridge, MA: Harvard University Press.

Rodrik, D. G. Grossman and V. Norman. 1995. 'Getting Interventions Right: How South Korea and Taiwan Grew Rich’, Economic Policy 10 (20): 53-107. doi.org/10.2307/1344538.

Rosser, A. 2007. 'Escaping the Resource Curse: The Case of Indonesia', Journal of Contemporary Asia 37 (1): 38-58. doi.org/10.1080/00472330601104557.

Roy, Pallavi. 2017. 'Anti-corruption in Nigeria: A political Settlements Analysis' Working Paper 002. London: SOAS, University of London.

Rudra, N. 2002. 'Globalization and the Decline of the Welfare State in LessDeveloped Countries', International Organization 56 (2): 411-445. doi. org/10.1162/002081802320005522.

Sandbrook, R. 2005. 'Origins of the Democratic Developmental State: Interrogating Mauritius', Canadian Journal of African Studies / Revue Canadienne Des Études Africaines 39 (3): 549-581. doi.org/10.1080/000839 68.2005.10751329.

Somos, M. 2011. “'A Price Would be Set not Only Upon our Friendship, But Upon our Neutrality’: Alexander Hamilton and Early American 
State-Building', in K. Stapelbroek (ed), Trade and War: The Neutrality of Commerce in the Inter-State System. Helsinki: Helsinki Collegium for Advanced Studies, 184-211.

Stapelbroek, K. and A. Trampus 2010. 'Commercial Reform against the Tide: Reapproaching the Eighteenth-Century Decline of the Republics of Venice and the United Provinces', History of European Ideas 36: 192-202. doi. org/10.1016/j.histeuroideas.2009.11.001.

Stark, R. 2014. How the West Won: The Neglected Story of the Triumph of Modernity. Delaware: ISI Books.

Stockwell, S. 2011. 'Democratic Culture in the Early Venetian Republic', in B. Isakhan and S. Stockwell (eds), The Secret History of Democracy. London: Palgrave Macmillan, 105-119.

Taxaide. 2020. 'Internally Generated Revenue at State Level - Full Year 2019 States ranking by IGR (Full year IGR share to total)'. https://taxaide.com. ng/2020/05/28/internally-generated-revenue-at-state-level-full-year-2019states-ranking-by-igr-full-year-igr-share-to-total/.

Tridimas, G. 2011. 'A Political Economy Perspective of Direct Democracy in Ancient Athens', Constitutional Political Economy 22: 58-82. doi. org/10.1007/s10602-010-9093-5.

Usman, Z. 2020. 'The Successes and Failures of Economic Reform in Nigeria's Post-Military Political Settlement', African Affairs 119 (474): 1-38. doi. org/10.1093/afraf/adz026.

Vasillopulos, C. 1995. 'The Nature of Athenian Hoplite Democracy', Armed Forces \& Society 22 (1): 49-63. doi.org/10.1177/0095327X9502200103.

Von Laue, T. H. 1951. 'The Industrialization of Russia in the Writings of Sergej Witte', The American Slavic and East European Review 10 (3): 177-190. doi.org/10.2307/2491509.

Whitfield, L., O. Therkilsden, L. Buur and A. M. Kjær. 2015. The Politics of African Industrial Policy: A Comparative Perspective. New York: Cambridge University Press.

World Bank. 2021a. 'GDP per capita (constant 2010 US\$) - Nigeria'. https:// data.worldbank.org/indicator/NY.GDP.PCAP.KD?locations $=\mathrm{NG}$.

World Bank. 2021b. 'GDP per capita growth (annual percent) - Nigeria'. https:// data.worldbank.org/indicator/NY.GDP.PCAP.KD.ZG?locations=NG.

Yat-sen, S. 1922. The International Development of China. New York \& London: G. Putnam's Sons. 